\title{
Scientific knowledge in the field of Physical Education: paths to complexity
}

\section{O conhecimento científico na Educação Física: caminhos para a complexidade}

Carolina Fernandes da Silva

(D) https://orcid.org/0000-0003-0026-1318

Abstract - This manuscript aims to discuss possibilities for the incorporation of complex thinking in the scientific field of Physical Education (PE) in Brazil. In dialogue with philosophers who theorize about complex thinking, we analyze the ordering of scientific knowledge structures in Brazil, such as the organization in areas and lines of PE Graduate Programs (PPGs) exposed on their websites and the Coordination for the Improvement of Higher Education Personnel (CAPES) document. Regarding sociocultural transformations that occurred throughout the $20^{\text {th }}$ century, science perceives the limits of knowledge, where divisions in disciplines seem to be insufficient to investigate the complexity of problems, giving rise to the epistemological perspective of complex thinking. $\mathrm{PE}$ is organized in a multidisciplinary and interdisciplinary way, but with gaps between human sciences and natural sciences. Therefore, seeking strategies to reduce borders is emerging for the area to adapt to the new scientific needs of the $21^{\text {st }}$ century.

Key words: Complex thinking; Epistemology; Interdisciplinary; Science.

Resumo - O presente manuscrito visa discutir sobre possibilidades de incorporação do pensamento complexo no campo científico da Educação Física (EF) no Brasil. Em diálogo com filósofos que teorizam sobre o pensamento complexo, analisa-seo ordenamento das estruturas do conhecimento cientifico no Brasil, como a organização em áreas e linhas dos Programas de Pós-Graduação (PPGs) da área, exposta em seus sites, e documento da Coordenação de Aperfeiçoamento de Pessoal de Ensino Superior (CAPES). Com as transformaçōes socioculturais ocorridas ao longo do século XX, a ciência percebe os limites do conhecimento, onde as divisões em disciplinas se mostram insuficientes para investigar a complexidade dos problemas, dando origem a perspectiva epistemológica do pensamento complexo. A EF organiza-se de forma multidisciplinar e interdisciplinar, porém com lacunas entre as Ciências Humanas e Ciência Naturais. Diante disso, buscar estratégias de redução das fronteiras é emergente para a área adequar-se as novas necessidades científicas do século XXI.

Palavras-chave: Ciência; Epistemologia; Interdisciplinaridade; Pensamento complexo.
1 Universidade Federal de Santa Catarina. Centro de Desportos. Departamento de Educação Física. Sôma - Núcleo de Estudos em Cultura, Corpo e Movimento. Florianópolis, SC. Brasil.

Received: March 06, 2020 Accepted: June 18, 2020

How to cite this article Silva CF. Scientific knowledge in the field of Physical Education: paths to complexity. Rev Bras Cineantropom Desempenho Hum 2020, 22:e74627. DOl: http://dx.doi.org/10.1590/1980 0037.2020v22e74627

Copyright: This work is licensed under a Creative Commons Attribution 4.0 International License. 


\section{INTRODUCTION}

As sociocultural changes occur, new theories, hypotheses, premises and laws that gave rise to scientific thought are reformulated to follow transformations that present new truths and uncertainties. In the $20^{\text {th }}$ century, the simple and general principles of science proved to be insufficient, thus emerging a new epistemological paradigm, the complexity of phenomena, where the dialogue between disciplinary perspectives emerges as one of the challenges to be faced ${ }^{1}$. In the context of scientific research, the area of knowledge identified as Physical Education (PE) in Brazil has other nomenclatures in other countries, namely: Physical Education, Kinesiology, Kinanthropology, Sport Sciences, among others ${ }^{2-5}$.

In these denominations, it is possible to identify elements that show the scientific epistemological heterogeneity. This point was highlighted by Renson ${ }^{2}$, who states that the area is identified as interdisciplinary with two disciplines (interdisciplinary), interdisciplinary with more than two disciplines (cross-disciplinary) or multidisciplinary, with more demarcated borders. In Brazil, however, when analyzing the ordering of Graduate Programs (PPGs), there is predominance of multidisciplinarity.

These conceptions have science organized into separate disciplines as a starting point for different relationships. Scientific disciplines are determined by a mental structure, called paradigm, which serves to classify the world and be able to approach it ${ }^{6}$. According to Fourez ${ }^{6}$, paradigms are the set of rules, principles, mental structures, instruments, cultural norms and/or practices that structure the discipline and are conditioned by the historical-sociocultural context to which they are inserted, which are subject to epistemological ruptures.

For Morin ${ }^{1}$, the disciplinary division of science has advantages and disadvantages; the work specialization generates conveniences such as the coherence of an organizing whole, but also the confinement and fragmentation of knowledge, and does not include the complexity of life. For philosopher Olga $\mathrm{Pombo}^{7}$, this division has yielded important fruits for science; however, it is insufficient today because it does not allow the whole to be reconstructed, which is a necessary change identified at the end of the $20^{\text {th }}$ century.

As an alternative to this scenario, Morin ${ }^{1}$ proposes the insertion of the complex thinking in the development of science, since we are beings at the same time physical, biological, social, cultural, psychic and spiritual. In this perspective, the same author ${ }^{1}$ points out that pertinent knowledge is able to place all information in its context and, if possible, in the set in which it is inserted, understanding its ambivalences, since the antagonistic and complementary relationship is what defines complexity. The argument for a complex approach to complex problems has been heard since the beginning of the $20^{\text {th }}$ century, although it has assumed greater sense of urgency as the magnitude and complexity of problems increases and demands an increase in praxis $^{3}$. 
The complex thinking methodology would have in PE a fertile field of application, as it is characterized by having several disciplinary approaches, since it understands that the various disciplines that compose it would help each other to understand the study objects, as the intelligence that only knows how to separate breaks the complexity of the world into isolated fragments ${ }^{8}$. By accepting to face the challenges imposed by this form of complex thinking, Brazilian PE would progress by adapting to a new scientific spirit, a movement already initiated by agencies that regulate Graduate Studies (PPGs) in the country ${ }^{9}$. Although this document does not make it clear how this will happen.

In this context, this manuscript aims to discuss possibilities for incorporating complex thinking in the scientific field of PE in Brazil.

\section{BRAZILIAN PHYSICAL EDUCATION AND DISCIPLINARY ORDERING}

In Brazil, the scientific field of $\mathrm{PE}$ has been organized with different nomenclatures related to theoretical perspectives, as can be seen in PPGs in the area: PE, Human Movement Sciences, PE and Sport, Physical Activity Sciences, Exercise and Sport Sciences, Motor Sciences and Sport Sciences. Currently, there are four PPGs in the field of PE elected as excellence by the Coordination for the Improvement of Higher Education Personnel (CAPES), namely: PPG in Physical Education and Sport at the University of São Paulo (PPGEEFE/USP) ${ }^{10}$; PPG in Physical Education at the Federal University of Parana (PPGEDF/UFPR $)^{11}$; PPG in Physical Education at the Federal University of Santa Catarina (PPGEF/UFSC) $)^{12}$ and PPG in Human Movement Sciences at the Federal University of Rio Grande do Sul (PPGCMH/UFRGS) ${ }^{13}$, which have disciplinary divisions with internal logic, as shown in Box 1, composed and decomposed in research areas and lines.

Even though the structures of these PPGs have been developed according to contextual spheres, such as the historically developed relationships of power disputes that structure scientific conceptions, the scientific organization of an area offers evidence of how scientific thinking is ordered. Box 1 shows how scientific organization of $\mathrm{PE}$ occurs and the divisions between Human Sciences and Natural Sciences, with small variations in the latter, which is divided into Biodynamics and Physical Activity and Health in PPGEDF/UFPR ${ }^{11}$ and PPGEF/UFSC ${ }^{12}$ graduate programs.

The authors ${ }^{3,5}$ highlight that this gap in scientific approaches has been deepened over time, continues to the present day and has been identified in $\mathrm{PE}$ internationally, intensifying a multidisciplinary character and limiting the possibilities of interdisciplinarity in the area ${ }^{2}$. Thus, interdisciplinary actions are limited in internal communications between disciplines that make up Natural Sciences, as well as within Human Sciences, as can be seen in texts that identify the PPGEDF/UFPR research lines (Box 1). 
Box 1. Organization of Physical Education PPGs in research areas and lines

\begin{tabular}{|c|c|c|}
\hline Program & Area & Research lines \\
\hline \multirow[t]{2}{*}{ PPGEEFE/USP } & $\begin{array}{l}\text { Sociocultural and Behavioral } \\
\text { Physical Education Studies }\end{array}$ & $\begin{array}{l}\text { - Organization of motor response and acquisition of motor skills; } \\
\text { - Analysis and diagnosis of motor development; } \\
\text { - Sociocultural studies of the human movement; } \\
\text { - Psychosocial aspects of sport; } \\
\text { - Management, Policies, Marketing and Communication in Sport and Physical } \\
\text { Education; } \\
\text { - Development of Physical Education programs. }\end{array}$ \\
\hline & $\begin{array}{l}\text { Biodynamic Physical Education } \\
\text { and Sport Studies }\end{array}$ & $\begin{array}{l}\text { - Biomechanics of human movement; } \\
\text { - Acute and chronic effects of exercise on the cardiovascular system; } \\
\text { - Nutrition, physical and genetic activity in sport and health; } \\
\text { - Sports performance. }\end{array}$ \\
\hline \multirow{3}{*}{ PPGEDF/UFPR } & $\begin{array}{l}\text { Sociocultural Aspects of Sport } \\
\text { and Leisure }\end{array}$ & $\begin{array}{l}\text { Involves studies and research focusing on manifestations related to sport and } \\
\text { leisure, with analyses from sociological, political, historical, philosophical, } \\
\text { educational and cultural perspectives. }\end{array}$ \\
\hline & Physical Activity and Health & $\begin{array}{l}\text { Involves studies and research on physical activity and exercise as a means of } \\
\text { promoting health in different populations and environments, with emphasis } \\
\text { on physiological, biomechanical, psychological, nutritional, epidemiological } \\
\text { and functional aspects. }\end{array}$ \\
\hline & $\begin{array}{l}\text { Physical and Sports Perfor- } \\
\text { mance }\end{array}$ & $\begin{array}{l}\text { Involves studies and research aimed at improving physical and sports in } \\
\text { different populations, developed from the perspectives of physiology, biome- } \\
\text { chanics, psychology and nutrition. }\end{array}$ \\
\hline \multirow{3}{*}{ PPGEF/UFSC } & $\begin{array}{l}\text { Pedagogical Theory and Prac- } \\
\text { tice in Physical Education }\end{array}$ & $\begin{array}{l}\text { - Theories of Body, Human Movement, Sports and Leisure; } \\
\text { - Pedagogical and Didactic Theories of Physical Education Teaching. }\end{array}$ \\
\hline & $\begin{array}{l}\text { Health-Related Physical } \\
\text { Activity }\end{array}$ & $\begin{array}{l}\text { - Physical Activity Promotion Programs and Processes; } \\
\text { - Physical Education, Living Conditions and Health. }\end{array}$ \\
\hline & $\begin{array}{l}\text { Biodynamics of Human Per- } \\
\text { formance }\end{array}$ & $\begin{array}{l}\text { - Biomechanics of Human Movement; } \\
\text { - Physical Exercise and Sports Performance. }\end{array}$ \\
\hline \multirow[b]{2}{*}{ PPGCMF/UFRGS } & $\begin{array}{l}\text { Human Movement, Culture and } \\
\text { Education }\end{array}$ & $\begin{array}{l}\text { - Social Representations of the Human Movement; } \\
\text { - Teacher Training and Pedagogical Practice. }\end{array}$ \\
\hline & $\begin{array}{l}\text { Human Movement, Health and } \\
\text { Performance }\end{array}$ & $\begin{array}{l}\text { - Physical Activity and health; } \\
\text { - Physical Activity and Performance; } \\
\text { - Neuromechanics of Human Movement. }\end{array}$ \\
\hline
\end{tabular}

Note. PPGEEFE/USP: Graduate Program in Physical Education and Sport at the University of São Paulo; PPGEDF/UFPR: Graduate Program in Physical Education at the Federal University of Paraná; PPGEF/UFSC: Graduate Program in Physical Education at the Federal University of Santa Catarina; PPGCMH/UFRGS: Graduate Program in Human Movement Sciences at the Federal University of Rio Grande do Sul.

In this context, it is clear that the organizations of scientific disciplines in $\mathrm{PE}$ are mostly multidisciplinary and interdisciplinary ${ }^{2}$. Multidisciplinarity aggregates disciplines in a parallelism of points of view; if these are outdated, in the sense of convergence and coordination between them, the interdisciplinary perspective is constituted ${ }^{7}$.

According to Renson ${ }^{2}$, multidisciplinarity consists of a set of separate disciplines that study a central theme, without integrating concepts. Such a format can be seen in the designations of areas and lines of knowledge of PE PPGs, which build the objects of study with terms such as physical exercise, physical activity, body and sport. Since the object of study is not born before the existence of the discipline that addresses it ${ }^{6}$, the conceptions expressed in the terms used demonstrate to which scientific approach they are linked and in line with theories adopted. 
In Brazil, the very location of PE in the Great Area of Health Sciences at CAPES contributes to the great gap ${ }^{5}$, since it is structured in the characteristics that the area imposes, linked to Life Sciences and, thus, with predominance of Natural Sciences. This location hinders - but does not prevent - the construction of knowledge in an interdisciplinary way and, thus, reduces the possibility of analyzing the object from different disciplinary angles, which creates other problems.

According to Article 207 of the Brazilian Federal Constitution ${ }^{14}$, Universities obey the principle of inseparability of teaching, research and extension, which triad must interact with each other, that is, the researcher transfers knowledge to teaching and extension activities and vice versa. However, when the researcher background is organized by areas of knowledge without integration, this knowledge is manifested in professional training at undergraduate level, generating the culture of the mass man, the assembled man assembling parts, which lacks own intimacy ${ }^{15}$. According to Morin ${ }^{8}$, the subject produces the mysterious quality called self-knowledge from complex thinking.

\section{TOWARDS COMPLEXITY OF BRAZILIAN PHYSICAL EDUCATION}

The scientific field of $\mathrm{PE}$ is composed of a diverse set of scientific disciplines, as identified in Box 1, ordered in research areas and lines that may vary in the different PPGs, that is, with more or less delimited boundaries based on theoretical and methodological affinities, multidisciplinary way, but with the possibility of developing border sciences. Border sciences are the new disciplines located on the border between two traditional disciplines ${ }^{7}$, fluid spaces between demarcation and communication, where the maze, the inextricable, the disorder, the ambiguity can occur, in short, the complexity, which arises where simplifying thinking fails ${ }^{1}$.

Unlike the current ordering of PPGs, for Morin ${ }^{1}$, knowledge cannot be limited within strict boundaries, nor can it expand and disperse, it must have space for knowledge interlocution. In the same direction, Olga $\mathrm{Pombo}^{7}$ states that scientific progress results from the presence of various languages and disciplines in the researcher's conscience. Thus, indivisible dimensions must be manifested in the investigative process, where knowledge is, therefore, a multidimensional inseparable phenomenon, simultaneously physical, biological, cerebral, mental, psychological, cultural, social ${ }^{8}$.

According to Patrícia Vertinsky ${ }^{3}$, in the 2000s, there were already changes in scientific approaches in $\mathrm{PE}$ research at international level, mainly in Kinesiology departments, especially when investigations tried to raise research funds from public and private agencies or educate students for newly created professions. In these departments, where health and body issues are generally recognized as central for physical activity studies, it has become clear to many that the complexity of these problems requires interdisciplinary approach focused on team problems ${ }^{3}$. 
In Brazil, this movement started to occur in fact recently, from the CAPES ${ }^{9}$ document, aiming at changes in PPGs evaluation for the next quadrennium. Such recommendations are based on the exchange of knowledge and propose PPGs as environments where the advancement and breaking of knowledge frontiers are encouraged, without imposition of disciplinary barriers, with attention to society, promoting dialogue between peers at national and international level ${ }^{9}$.

However, for this to happen, it needs to break with historically established disputes that deepened the rupture of the area into Human Sciences and Natural Sciences ${ }^{4}$. By overcoming this challenge, PE would become truly interdisciplinary by assuming that the pertinent knowledge is capable of placing all information in its context and, if possible, in the set in which it is inserted ${ }^{8}$, towards a complex thought about the objects it addresses.

It seems that this way of thinking about science will be used by CAPES in the coming years for the evaluation of programs that assume that the final product to be evaluated is the solution of a problem (or bottleneck) demanded by society that it is usually complex, and, as a rule, requires interdisciplinarity for its solution?. Box 2 presents possible strategies for bringing human and natural sciences closer together in PE PPGs based on the types of interdisciplinary crossing.

Box 2. New interdisciplinary crossing practices?

\begin{tabular}{|l|l|}
\hline Practices & Type of interdisciplinary \\
\hline Importation & $\begin{array}{l}\text { A central discipline co-opts the work regarding methodologies, languages and equipment already } \\
\text { used in another discipline. }\end{array}$ \\
\hline Crossing & $\begin{array}{l}\text { Opening each discipline to all the others, disciplines allow themselves to be contaminated and } \\
\text { crossed with elements characteristic of each one. }\end{array}$ \\
\hline Convergence & Studies by areas involving convergence of perspectives. \\
\hline Decentralization & $\begin{array}{l}\text { When traditional disciplines are not sufficient for the knowledge of specific problems or are too } \\
\text { large. There is no discipline that constitutes the point of departure or irradiation of the problem, } \\
\text { nor even the point of arrival of work. }\end{array}$ \\
\hline Commitment & $\begin{array}{l}\text { For issues too vast that have resisted over the centuries. Where our knowledge is few to even } \\
\text { notice, an engaging and circular interdisciplinarity is needed, which actively explores all possible } \\
\text { complementarities between disciplines. }\end{array}$ \\
\hline
\end{tabular}

A plan to incorporate interdisciplinarity into PE PPGs can be organized from the simplest to the most complex. At first, it could institute two types of interdisciplinary practices, that of importation and that of convergence, and other practices could be later introduced.

\section{CONCLUSION}

This manuscript sought to discuss possibilities for incorporating complex thinking into the scientific field of PE in Brazil. The elements presented allowed reflecting on the main current characteristics of PPGs of excellence in the area, which are organized in a multidisciplinary way. As complex thinking determines fluidity between boundaries of scientific disciplines, the modification of some structures in areas and lines of these PPGs, 
promoting interdisciplinarity, will allow research to address the complex problems that contemporaneity provides.

The challenge of adopting complexity as a motivation for thinking has emerged over the decades of the $20^{\text {th }}$ century and will erupt in the $21^{\text {st }}$ century. New proposals for incorporating this thinking are emerging but for this to occur, it is necessary to face incompleteness and uncertainty that its paths lead to: the irreducibility of chance and disorder; the transgression of the limits of universalist abstraction that eliminates singularity, locality and temporality; the complication; a complementary relationship between order, disorder and organization; and the organization that constitutes a unit and a multiplicity, where not only the part is in the whole, but the whole is in the part ${ }^{1}$. However, perhaps the greatest challenge of Brazilian $\mathrm{PE}$ is to break with walls raised among scholars of Human Sciences and Natural Sciences for the definition and mastery of the field.

\section{COMPLIANCE WITH ETHICAL STANDARDS}

\section{Funding}

This research did not receive any specific grant from funding agencies in the public, commercial, or no-profit sectors. This study was funded by the authors.

\section{Ethical approval}

The protocol research was written in accordance with standards set by the Declaration of Helsinki.

\section{Conflict of interest statement}

The author has no conflict of interest to declare.

\section{Author Contributions}

Developed and coordinated the study: CFS; Data collection: CFS; Data analysis: CFS; Wrote the article: CFS.

\section{REFERENCES}

1. Morin E. Ciência com consciência. 8. ed. Rio de Janeiro: Bertrand; 2005.

2. Renson R. From Physical Education to Kinanthropology: A Quest for Academic and Professional Identity. Quest 1989;41(3):235-256.

3. Vertinsky P. Mind the Gap (or Mending It): Qualitative Research and Interdisciplinarity in Kinesiology. Quest 2009;61(1):39-51.

4. Twietmeyer G. What is Kinesiology? Historical and Philosophical Insights. Quest 2012: 64(1):4-23.

5. Isidori E, Frías J. Sport, science, and complexity: a pedagogical and methodological reflection. Studia UBB Educatio Artis Gymn 2014;59(3):5-13.

6. Fourez G. A construção das ciências: introdução à filosofia e à ética das ciências. São Paulo: Editora da Universidade Estadual Paulista, 1995.

7. Pombo O. Epistemologia da interdisciplinaridade. Ideação 2008;10(1):9-40.

8. Morin E. O Método 3: conhecimento do conhecimento. 5. ed. Porto Alegre: Sulina; 2015. 
9. Brasil. Coordenação de Aperfeiçoamento de Pessoal de Nível Superior (CAPES). Comissão Especial de Acompanhamento do Plano Nacional de Pós-Graduação - PNGG 2011-2020, e está intitulado como Proposta de Aprimoramento da Avaliação da Pós-Graduação Brasileira para o Quadriênio 2021-2024 - Modelo Multidimensional; 2020. [acesso em: 9 de junho de 2020]. Disponível em: http://www.capes.gov.br/images/novo_portal/documentos/PNPG/25052020_ Relat\%C3\%B3rio_Final__2019_Comiss\%C3\%A3o_PNPG.pdf .

10. PPGEEFE/USP [internet]. Programa de Pós-Graduação da Escola de Educação Física e Esporte da Universidade de São Paulo [acesso em: 9 de junho de 2020]. Disponível em: http://www.eefe.usp.br/\%C3\%A1reas-deconcentra\%C3\%A7\%C3\%A3o..

11. PPGEDF/UFPR [internet]. Programa de Pós-Graduação em Educação Física da Universidade Federal do Paraná [acesso em: 9 de junho de 2020]. Disponível em: http://www.prppg.ufpr.br/site/ppgedf/pb/.

12. PPGEF/UFSC [internet]. Programa de Pós-Graduação em Educação Física da Universidade Federal de Santa Catarina [acesso em: 9 de junho de 2020]. Disponível em: https://ppgef.ufsc.br/o-programa/areas-de-concentracao-e-linhasde-pesquisa/.

13. PPGCMH/UFRGS [internet]. Programa de Pós-Graduação em Ciências do Movimento Humano da Universidade Federal do Rio Grande do Sul [acesso em: 9 de junho de 2020]. Disponível em: http://www.ufrgs.br/ppgemh/site/pesquisa/linhas.

14. Brasil, Constituição. Constituição da República Federativa do Brasil. Brasília (DF): Senado Federal; 1988 [acesso em: 9 de junho de 2020]. Disponível em: https:// www.senado.leg.br/atividade/const/con1988/con1988_18.02.2016/art_207_. asp\#: :text=Art.,entre\%20ensino\%2C\%20pesquisa\%20e\%20extens\%C3\%A3o.

15. Ortega Y Gasset J. A rebelião das massas. São Paulo: Martins Fontes; 1987.

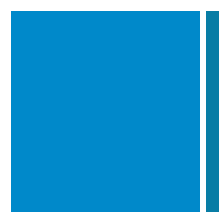

Corresponding author

Universidade Federal de Santa Catarina - Santa Catarina/Brasil

Centro de Desportos. Departamento de Educação Física

Sôma - Núcleo de Estudos em Cultura, Corpo e Movimento

Campus Universitário, Trindade 88040-900, Florianópolis, SC.

E-mail: carolina.f.s@ufsc.br 